Kong. Res. J. 4(2): 19-23, 2017

ISSN 2349-2694

Kongunadu Arts and Science College, Coimbatore.

\title{
PHYTOSOCIOLOGICAL ANALYSIS AND FLORISTRIC DIVERSITY OF VANEESWARAM KAVU IN KANNUR DISTRICT, KERALA
}

\author{
Jeeshna, M.V. \\ Department of Botany, Sree Narayana College, Thottada, Kannur, Kerala - 670007. \\ E.mail: mvjeeshna@gmail.com
}

\begin{abstract}
Sacred groves act as a treasure house for rare and medicinal plants. Apart from the quantitative analysis quantitative approach to sacred grove gives the potential species and importance of sacred grove, which is the main focuses of this work. There are many sacred grooves are present at Kannur district in which Vaneeswaram Kavu is one of the important one. The flora of sacred groves of has analysed taxonomically and phytosociologically. A total of 64 vascular plants falling under 61 genera and 43 families were documented. About 12 species are reported in the red listed category. In phytosociological studies species like, Elaeocarpus serratus, Erycibe paniculata and Scleria lithosperma were showing higher IVI. The devastation of species diversity in the study area represent there is an urgent need for regeneration of the species for conservation of biodiversity.
\end{abstract}

Keywords: Sacred grove, phytosociology, biodiversity, regeneration.

\section{INTRODUCTION}

The groves are small patches of vegetation types that were traditionally protected and managed by the local communities, through a wide range of management practices (Gadgil and Vartak, 1976). Sacred grooves have existed from time immemorial as patches of densely wooded areas with unique flora and fauna and perennial water sources in their vicinity. These sacred grooves are considered valuable gene pool and the first major effort to recognize and conserve biodiversity. In many parts of India, sacred grooves symbolize surviving examples of climax vegetation and are disappearing with modernization. As an ecosystem, they help in soil and water conservation, preserves the biological wealth, treasure house of rare and endangered animal species abode of many medicinal, endemic, endangered an economically important plants. Sacred grooves are important ecological centres to study the potential vegetation and source to gather indigenous knowledge on local plants, animals, habitat preferences, distribution, life histories and demographic features. Cultural practices and folk beliefs related to sacred groves imply conservation measures of ecosystems and labelled ethno forestry (Pandey 1998).

In Kerala, based on ownership patterns, sacred groves (Kavu in the regional language, Malayalam) can be broadly categorised into three groups namely those managed by individual families, group of families and the statutory bodies for temple management (Devaswom Board). The present study of sacred grove, Vaneeswaram Kavu, Kannur district, Kerala focuses on analyzing floristic composition, medicinal properties and red listed species in the selected area.

\section{MATERIALS AND METHODS}

\subsection{Study area}

The study area, Vaneeswaram Kavu (Fig.1) is concentrated in Kannur district, which is located in the northern part of Kerala. The sacred grove is located in Morazha central, which is about 14 kilometers long from Kannur town. The temple lies between $11.987^{\prime} \mathrm{N}$ latitude and $75.349^{\prime} \mathrm{E}$ longitude. Here, the climate is very hot and humid with minimum and maximum temperature ranging from $27^{\circ} \mathrm{C}$ to $31^{\circ} \mathrm{C}$. The average annual rainfall is 3614 $\mathrm{mm}$. The study area of sacred grove spread out in one and half acres. Here the worship is "Nagam" (snake).

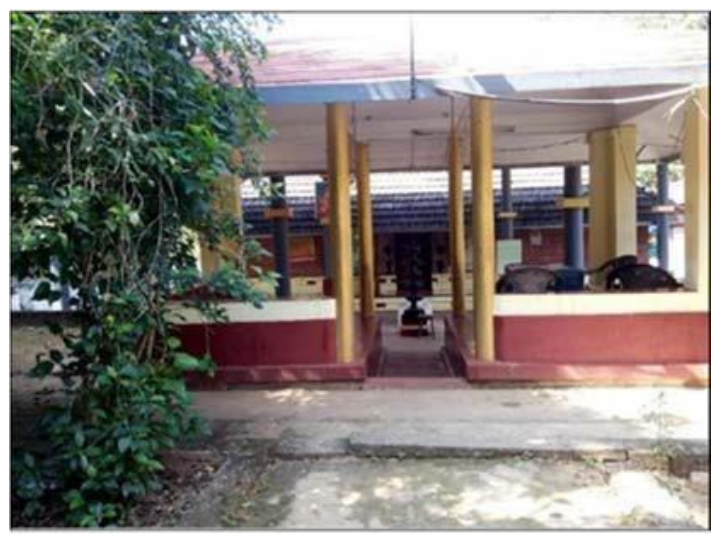

Fig. 1. Vanneswaram Kavu, Morazha, Kannur district. 


\subsection{Floristic survey}

Field surveys were carried out to know their exact location, extent, presiding deity etc. Whenever any sacred groves visited the neighbouring people and temple worshippers were interviewed to confirm the above facts and also to elicit information about the presence other groves in the vicinity. The extent each grove was ascertained by discussion with local people and latter confirmed with temple records. Plants are identified with the help of Madras Presidency (Gamble, 1915-1936), Flora of Cannanore (Ramachandran and Nair, 1988) and also by using available field keys and taxonomic bulletins. The identification was further confirmed with the help of taxonomic experts in Botany.

\subsection{Phytosociological analysis}

The minimum quadrat size of $1 \mathrm{x} 1$ was fixed by the species- area curved method of phytosociological observations. Each time 20 quadrats were laid by the randomized method in each site. The minimum number of quadrat required (ie. 20) was determined as described by Greig Smith (1974).

The number and type of each species occurring in each quadrat were recorded. For grasses, each tiller was counted as an individual because it is impossible to decide from aerial shoots whether it is separated or connected in the subterranean region, especially in perennial grasses. Different workers have used arbitrary units to represent individual. Armstrong (1907) and Stapledon (1913) have counted the entire individuals as far as possible in the case of erect plants, but in creeping grasses each grasses each rooting units has taken as an individual. Stove and Fryer (1935) have considered an independent root system, as nearly as this could be determined without actually lifting the plant, to be a unit for counting. In the case of creeping plants, any portion of the plant upto $5 \mathrm{~cm}$ in length and having functional root was counted as one plant. Only the plants beyond seedling stage (ie. more than $2 \mathrm{~cm}$ height in case of monocots and beyond first leaf stage in dicots) were counted. The basal areas at the point of emergence for the constituent species were measured. From the observations, the quantitative characters such as frequency, density, abundance, relative frequency, relative density, relative dominance, importance value index and relative value of importance were calculated (Shukla and Chandel, 1982; Misra, 1980).

Frequency, density and abundance were calculated using the following formulae:

$$
\begin{gathered}
\text { Frequency }=\frac{\text { Number of quadrats in which the species present }}{\text { Total number of quadrats studied }} \times 100 \\
\text { Density }=\frac{\text { Total number of individuals of the species in all quadrats }}{\text { Total number of quadrats studied }} \\
\text { Abundance }=\frac{\text { Total number of individuals of the species in all quadrats }}{\text { Number of quadrats of occurrence of the species }} \\
\text { Basal area }=\Pi r^{2}
\end{gathered}
$$

( $\Pi=3.14$ and ' $r$ ' is the radius of the stem at the point of emergence.)

Relative frequency, relative density and relative dominance were calculated from the following formulae:

$$
\begin{gathered}
\text { Relative Frequency }=\frac{\text { Number of occurence of the species }}{\text { Number of occurence of all species }} \times 100 \\
\text { Relative density }=\frac{\text { Number of individuals of the species }}{\text { Number of individuals of all species }} \times 100 \\
\text { Relative dominance }=\frac{\text { Total basal area of the species }}{\text { Total basal area of all species }} \times 100 \\
\text { IVI }=\text { RD }+ \text { RF }+ \text { RDo } \\
\text { RIVI }=I V I / 3
\end{gathered}
$$

\subsection{Ethnobotanical studies and phytosociological analysis}

During the field visits, the various uses of plants were gathered. 65 species were recorded by adopting Quadrat method of sampling. The biodiversity induces like frequency, density, abundance, basal cover and important value index and their synthetic attributes like relative frequency, relative density, relative dominance, and relative value of importance were calculated.

\section{RESULTS AND DISCUSSION}

Among the 64 species available $93 \%$ plant possessed medicinal uses. It indicates the potentiality of two study areas for the inhabitation of medicinal plants. It may be explained that the sacred groves are rich collection of conserved medicinal plants (Vinothkumar et al., 2011). The uses of species for diverse medicinal purposes show the production of different kinds of secondary metabolites with rich varieties of bioactive compounds in the study sites.

There are 12 endangered species in the study area (Table 2). According to Bhagwat (2005) sacred groves are the last home of some endangered species and also are known to represent the only existing climax vegetation communities in Northeastern India. 
Table 1. Species composition of Vanneswaram kavu, Morazha, Kannur.

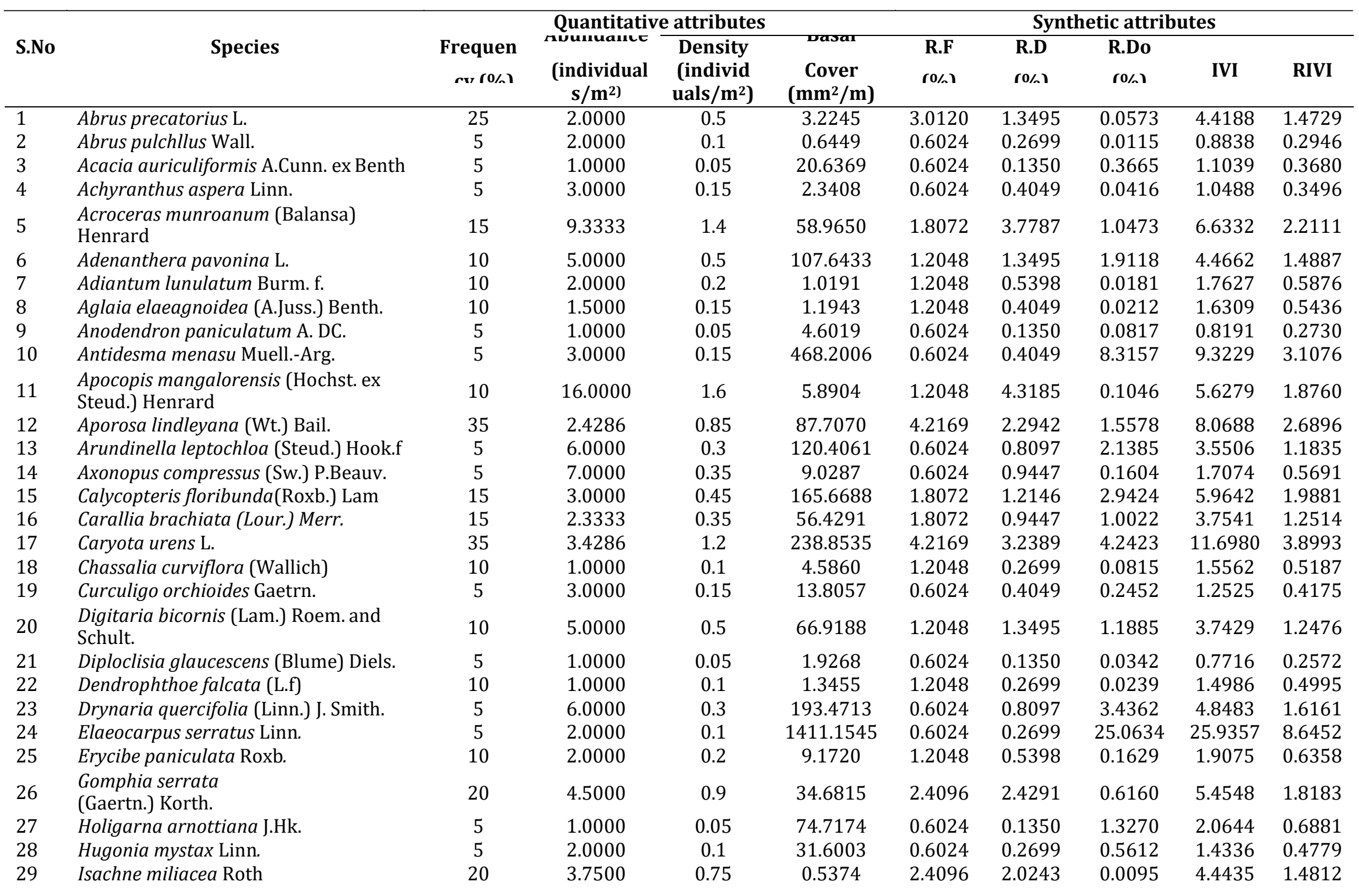




\begin{tabular}{|c|c|c|c|c|c|c|c|c|c|c|}
\hline 30 & Ischaemum indicum (Houtt.) & 20 & 20.5000 & 4.1 & 1.3057 & 2.4096 & 11.0661 & 0.0232 & 13.4990 & 4.4997 \\
\hline 31 & Ischaemum timorense Kunth & 10 & 6.0000 & 0.6 & 0.1911 & 1.2048 & 1.6194 & 0.0034 & 2.8276 & 0.9425 \\
\hline 32 & Ixora brachiata Roxb. & 5 & 2.0000 & 0.1 & 3.1847 & 0.6024 & 0.2699 & 0.0566 & 0.9289 & 0.3096 \\
\hline 33 & Ixora coccinea $\mathrm{L}$ & 20 & 2.7500 & 0.55 & 19.3113 & 2.4096 & 1.4845 & 0.3430 & 4.2371 & 1.4124 \\
\hline 34 & Jasminum flexile Vahl. & 10 & 2.0000 & 0.2 & 1.0191 & 1.2048 & 0.5398 & 0.0181 & 1.7627 & 0.5876 \\
\hline 35 & Jasminum malabaricum Wight & 10 & 1.0000 & 0.1 & 7.1656 & 1.2048 & 0.2699 & 0.1273 & 1.6020 & 0.5340 \\
\hline 36 & Kyllinga nemoralis L. & 5 & 5.0000 & 0.25 & 25.7962 & 0.6024 & 0.6748 & 0.4582 & 1.7353 & 0.5784 \\
\hline 37 & Leea indica (Burm.f.) Merr. & 15 & 2.0000 & 0.3 & 27.6115 & 1.8072 & 0.8097 & 0.4904 & 3.1073 & 1.0358 \\
\hline 38 & Lepidagathis incurve D.Don & 5 & 2.0000 & 0.1 & 4.5860 & 0.6024 & 0.2699 & 0.0815 & 0.9538 & 0.3179 \\
\hline 39 & Lepisanthes tetraphylla (Vahl) Radlk & 10 & 1.5000 & 0.15 & 4.7771 & 1.2048 & 0.4049 & 0.0848 & 1.6945 & 0.5648 \\
\hline 40 & Lindsaea ensifolia Sw. & 10 & 1.0000 & 0.1 & 1.1465 & 1.2048 & 0.2699 & 0.0204 & 1.4951 & 0.4984 \\
\hline 41 & Macaranga peltata Roxb. Mueller & 5 & 1.0000 & 0.05 & 14.3312 & 0.6024 & 0.1350 & 0.2545 & 0.9919 & 0.3306 \\
\hline 42 & Mangifera indica $\mathrm{L}$. & 5 & 1.0000 & 0.05 & 57.3248 & 0.6024 & 0.1350 & 1.0181 & 1.7555 & 0.5852 \\
\hline 43 & Melicope lunu-ankenda (Gaertn.) & 10 & 1.0000 & 0.1 & 29.6258 & 1.2048 & 0.2699 & 0.5262 & 2.0009 & 0.6670 \\
\hline 44 & Memecylon talbotianum Burm.f. & 20 & 3.2500 & 0.65 & 67.0701 & 2.4096 & 1.7544 & 1.1912 & 5.3552 & 1.7851 \\
\hline 45 & Mimosa pudica Linn. & 10 & 5.0000 & 0.5 & 4.8169 & 1.2048 & 1.3495 & 0.0856 & 2.6399 & 0.8800 \\
\hline 46 & Olea dioica Roxb. & 30 & 2.0000 & 0.6 & 61.9108 & 3.6145 & 1.6194 & 1.0996 & 6.3335 & 2.1112 \\
\hline 47 & Piper trioicum L. & 5 & 4.0000 & 0.2 & 1.9268 & 0.6024 & 0.5398 & 0.0342 & 1.1764 & 0.3921 \\
\hline 48 & Pothos scandens L. & 25 & 1.8000 & 0.45 & 6.0549 & 3.0120 & 1.2146 & 0.1075 & 4.3342 & 1.4447 \\
\hline 49 & $\begin{array}{l}\text { Pseuderanthemum latifolium (Vahl)B. } \\
\text { Hansen }\end{array}$ & 5 & 2.0000 & 0.1 & 4.2118 & 0.6024 & 0.2699 & 0.0748 & 0.9471 & 0.3157 \\
\hline 50 & Rourea minor (Gaertn.) Aubl. & 20 & 6.0000 & 1.2 & 50.5414 & 2.4096 & 3.2389 & 0.8977 & 6.5462 & 2.1821 \\
\hline 51 & Rungia pectinata (L.) Nees. & 15 & 4.0000 & 0.6 & 37.4522 & 1.8072 & 1.6194 & 0.6652 & 4.0918 & 1.3639 \\
\hline 52 & Salacia fruticosa Wall. & 10 & 2.0000 & 0.2 & 20.6369 & 1.2048 & 0.5398 & 0.3665 & 2.1112 & 0.7037 \\
\hline 53 & Santalum album L. & 10 & 2.0000 & 0.2 & 321.0828 & 1.2048 & 0.5398 & 5.7027 & 7.4473 & 2.4824 \\
\hline 54 & Sarcostigma kleinii Wight and Arn. & 5 & 4.0000 & 0.2 & 39.8089 & 0.6024 & 0.5398 & 0.7070 & 1.8493 & 0.6164 \\
\hline 55 & Scleria lithosperma (L.) Sw. & 25 & 22.0000 & 5.5 & 343.3121 & 3.0120 & 14.8448 & 6.0975 & 23.9544 & 7.9848 \\
\hline 56 & Smilax zeylanica $L$. & 35 & 1.7143 & 0.6 & 10.7484 & 4.2169 & 1.6194 & 0.1909 & 6.0272 & 2.0091 \\
\hline 57 & Staurogyne glauca Kuntze & 15 & 3.3333 & 0.5 & 4.8169 & 1.8072 & 1.3495 & 0.0856 & 3.2423 & 1.0808 \\
\hline 58 & Stemodia verticillata (Mill.) Hassler & 10 & 1.5000 & 0.15 & 7.4642 & 1.2048 & 0.4049 & 0.1326 & 1.7422 & 0.5807 \\
\hline 59 & Strychnos nux-vomica L & 55 & 6.8182 & 3.75 & 659.5342 & 6.6265 & 10.1215 & 11.7139 & 28.4619 & 9.4873 \\
\hline 60 & Syzygium caryophyllatum (L.) Alston & 5 & 2.0000 & 0.1 & 101.6640 & 0.6024 & 0.2699 & 1.8056 & 2.6780 & 0.8927 \\
\hline 61 & Uvaria narum Wall. & 25 & 5.0000 & 1.25 & 238.9530 & 3.0120 & 3.3738 & 4.2440 & 10.6299 & 3.5433 \\
\hline 62 & Vanda roxburghii R. Br. & 15 & 9.0000 & 1.35 & 189.6019 & 1.8072 & 3.6437 & 3.3675 & 8.8185 & 2.9395 \\
\hline 63 & Vitex altissima L.f. & 20 & 2.2500 & 0.45 & 63.2006 & 2.4096 & 1.2146 & 1.1225 & 4.7467 & 1.5822 \\
\hline 64 & Wattakakka volubilis (L.f.) Stapf & 5 & 2.0000 & 0.1 & 1.7914 & 0.6024 & 0.2699 & 0.0318 & 0.9041 & 0.3014 \\
\hline
\end{tabular}

R.F-Relative Frequency, R.D- Relative Density, R.Do- Relative Dominance, IVI- Important Value Index, RIVI- Relative Important Value Index. 
Table 2. Red listed plants in Vaneeswaram Kavu, Kerala.

\begin{tabular}{cll}
\hline $\begin{array}{c}\text { Si } \\
\text { No }\end{array}$ & \multicolumn{1}{c}{ Species } & \multicolumn{1}{c}{ Status } \\
\hline 1 & $\begin{array}{l}\text { Aglaia elaeagnoidea (A.Juss.) } \\
\text { Benth. }\end{array}$ & $\begin{array}{l}\text { Least } \\
\text { concerned }\end{array}$ \\
& Anodendron paniculatum A. DC. & Endangered \\
2 & Arundinella leptochloa (Steud.) & Least \\
3 & Hook.f & Concerned \\
& Curculigo orchioides Gaetrn. & Endangered \\
4 & Drynaria quercifolia (L.) J. Sm. & Endangered \\
5 & Holigarna arnottiana J.Hk. & Least \\
6 & & concerned \\
& Least \\
7 & Ixora brachiata Roxb. & concerned \\
8 & Masminum malabaricum Wight & Endangered \\
9 & Melicope lunu-ankenda (Gaertn.) & Endangered \\
10 & Santalum album L. & Endangered \\
11 & Staurogyne glauca Kuntze. & Endangered \\
12 & Syzygium caryophyllatum (L.) & Endangered \\
& Alston & \\
\hline
\end{tabular}

Out of the 64 species in Vanneswaram Kavu Strychnos nux-vomica, Aporosa lindleyana, Caryota urens and Smilax zeylanica shows better frequency value. But Scleria lithosperma, Ischaemum indicum and Apocopis mangalorensis have distributed abundantly than the other constituent species. Highest density was observed in the species like Scleria lithosperma, Ischaemum indicum, Strychnos nux-vomica. Based on the basal cover, Elaeocarpus serratus was considered to be the dominant species and secured the basal cover of $1411 \mathrm{~mm}^{2} / \mathrm{m}$. In this site species like Strychnos nux-vomica, Scleria lithosperma, Elaeocarpus serratus were registered highest Relative frequency, Relative density and Relative basal cover respectively. Of the various plant species available, Strychnos nux-vomica securing higher IVI of 28.46 (Table.1). According to Misra (1980) this may be attributed to their high reproductive capacity, quick dispersal of seeds and wind pollination to produce viable seeds. Their existence is also due to certain taboos, strong and supplemented mystic folklore (Gadgil and Vartak, 1975).

The present study envisages toreveal the potentiality for its richness of biodiversity and ecological status of the sacred grove. It is suggested that the studied sacred groves must be given conservation priority to protect valuable endangered medicinal species. Despite the seasonal changes, the anthropogenic were determined to be most influencing factor to affect the species composition and the quantitative ecological attributes of many sensitive species. Therefore construction activities, over grazing, collection of fire wood, tress passing, dumping of waste and many antisocial elements must be checked so as to protect the species in their habitats. Further, ecosystem- specific management plans must be developed to protect the individual species in these sacred groves. Protection of such activities aid in the regulation of ecological process like energy flow, food chain and food web and cycling of materials which would result in ecological balance and stability of ecosystem.

\section{REFERENCES}

Armstrong, S.F. (1907). The botanical and chemical composition of herbage pastures and meadows. J. Agr. Sci 2: 283-304.

Bhagwat, S.A., C.G. Kushalappa, P.H. Williams and N.D. Brown (2005). A land scape approach to biodiversity conservation of sacred groves in the Western Ghats of India. Conserv. Biol 19(6): 1853-1862.

Gadgil, M. and V.D. Vartak, (1975). Sacred groves of India: a plea for continued conservation. J. Bombay Nat. His. Soc 72: 314-320.

Gadgil, M. and V.D. Vartak, (1975). Sacred groves of India-A plea for continued conservation. J. Bombay Nat. Hist. Soc 73: 623- 647.

Gamble, J.S. and C.E.C. Fischer, (1915-1935). Flora of presidency of Madras, Adlord and Sons Ltd, London.

Grieg-Smith, P. (1974). Quantitative plant ecology $2^{\text {nd }}$ (eds.), Butterworths, London.

Misra, K.C. (1980). Manual of Plant Ecology, Oxford and IBH publishing co., New Delhi, Bombay and Calcutta. p. 457.

Pandey, D.N. (1998). Ethnoforestry: local knowledge for sustainable forestry and livelihood security. Himanshu Publications. Udaipur, New Delhi.

Ramachandran, V.S. and V.J. Nair (1988). Flora of Cannanore. pp.1-599.

Shukla, R.S. and P.S. Chandel, (1982). A Text Book of Plant Ecology. S. Chand and Company. Limited, pp. 107-146.

Stapledon, R.G. (1913). Pasture problems and drought resistance. J. Agric. Sci 5: 129-151.

Stove, W.C. and J.R.A. Fryer, (1935). A botanical study of pasture mixtures. Sci. Agric 15: 777805.

Vinothkumar, D., S. Murugavelh and A. Kethsy Prabhavathy, (2011). Phytosociological and ethenobotanical studies of sacred groves in Pudukottai District, Tamil Nadu, India. Asian J Exp. Biol. Sci 2(2): 306-315. 